for March 16th a paper entitled 'A propos de la question du climat des temps glaciaires,' in which he states it as his belief that the problem of the climate of glacial periods will be solved through a careful study of the meteorological and other conditions of the Antarctic.

Mr. H. N. Dickson, lecturer in physical geography in the University of Oxford, contributes a paper on 'The Circulation of the Surface Waters of the North Atlantic Ocean' to the Philosophical Transactions of the Royal Society of London, Series A, Vol. 196, pp. 61-203. The plates, which are colored, show the monthly distribution of temperature and of salinity in the surface waters of the North Atlantic during the years 1896 and 1897.

'Cloud observations during 1896 and 1897 at Toronto' is the title of a recent publication of the Meteorological Service of the Dominion of Canada (4to, Toronto, 1901, pp. 27). These observations were begun September 21, 1896, and were made by means of theodolites. The full tables of observations are given, but there is no discussion of the results, there being only the briefest summary of average altitudes and velocities by months.

Mаммотн Tank, in the eastern portion of San Diego Co., Cal., on the line of the Southern Pacific R. R., is one of the most interesting meteorological stations in the United States. 'The Climatology of Mammoth Tank' is the title of a brief article in the February number of Climate and Crops: California Section. The mean annual rainfall for 23 years is 1.81 inches. The maximum temperature recorded was $130^{\circ}$, on Aug. 17, 1878. The warmest month is July, with a mean temperature of $98.5^{\circ}$.

R. DeC. WARD.

\section{FRANCOIS QUESNAY.}

The Smithsonian Institution has received a Livre d 'Or, published in commemoration of $\mathrm{M}$. François Quesnay, who died in December, 1774 , at the age of eighty years, and was buried at his birthplace, Méré, Seine-et Oise, France.

The monument and book were the project of the Société populaire, of which M. J. Allain-Le Canu was president and prime mover. The monument was determined upon at Méré dur- ing the Fête Scolaire held July 10, 1892, and was completed and inaugurated August 23, 1896. At both ceremonies there were large attendance and great enthusiasm. At the former, addresses were delivered by M. Quesnay de Beaurepaire, the great-grandson of him whom they honored, and at the latter by MM. Bourgeat, representing the Minister of Public Instruction and Beaux Arts, Frederick Passy, M. Bellan and M. Marcel Habert.

M. François Quesnay was an ignorant country boy. He did not learn to read until after he was eleven years old, when he became enamored of the science of medicine, in which he acquired such skill as that he was appointed physician to the King, Louis XV. He became the founder of the science of political economy in France, and finally one of the most learned men of his country and his age. His eminence in these branches of science was such that, two hundred years after he was born, his friends and the neighbors of his town, desiring to give him honor according to his renown, erected a monument in his memory in the town of his birth.

Alexander Quesnay, descendant of François, came to America and fought on her side during the War, of Independence. He remained here after the war, taking up his residence in Richmond, Va., where he was chosen and served as president of the Academy.

Thomas Wilgon.

\section{A SUMMARY OF WISCONSIN ARCHEOLOGY.}

Members of the Wisconsin Society of Natural History are making systematic efforts to summarize the data of Wisconsin archeology and to preserve the archeological records, specimens and mounds of the State. A committee has been appointed for this purpose. It consists of C. D. Stanhope, H. Denison, W. J. Bennetts and Charles E. Brown. This committee has prepared a circular letter to be sent to every person in the State who is thought to be interested in the archeology of Wisconsin.

There are about three hundred collections of specimens from Wisconsin, varying in size from five hundred to five thousand objects, which 
are known to be in different parts of the State. There are no headquarters for these collections, or for a typical series from them, nor is there any record covering the entire range of forms or number of geographical areas. Many specimens pass to foreign countries without a record or photographs being taken for the State. It is not the desire of the Wisconsin people to prevent the study of the antiquities of the State by outsiders or even their acquirement of specimens, but rather to secure records, drawings and other data for a central State collection to be available for study by all. Eventually State appropriations for a survey of the mounds are to be sought.

The Wisconsin Society of Natural History was founded by Increase Lapham and others, who began archeological work on a firm basis. It now proposes to establish a new grade of membership in the archeological section, for people living at a distance from Milwaukee. The regular membership fee is three dollars per year. The fee for the new grade will be one dollar. A meeting will be held at the Milwaukee Public Museum in May, to which all known students and collectors of Wisconsin archeology residing in the State will be invited. The object of this meeting will be to discuss ways and means for the study and preservation of Wisconsin antiquities.

It is hoped that students and collectors will be brought into closer relationship by the publication of a bulletin, which, it is expected, will be established as a result of this meeting. The foundation of an anthropological reference library, the lack of which is keenly felt, and a central place of record, where reports of explorations may be heard and discussed, is also expected by the committee as an outcome of the meeting.

The people interested in this movement may do lasting good by striving to preserve the prehistoric mounds by enclosing them in parks, by a close cooperation with the State University, by a broadening of the proposed archeological research into that of general ethnology, and, finally, by the foundation of a permanent department of anthropology in the University.

HARLAN I. SMITH.
SCIENTIFIC NOTES AND NEWS.

AT the annual meeting of the American Academy of Arts and Sciences, held on May 8th, it was unanimously voted to award the Rumford Medal to Professor Elihu Thomson 'for his inventions in electric welding and lighting.' The Academy has granted to Professor Theodore W. Richards, of Harvard University, the sum of $\$ 500$ from the income of the Rumford Fund, in aid of a research upon the Thomson Joule effect.

Professor J. H. VAN'T HoFF, of the University of Berlin, will give a limited number of lectures on physical chemistry at the Kent Chemical Laboratory of the University of Chicago, beginning on June 19, 1901.

M. Berthelot, the eminent chemist, exMinister for Foreign Affairs, and permanent secretary of the Paris Academy of Sciences, who has been elected a member of the French Academy in succession to M. Bertrand, the mathematician, was officially welcomed to the Academy by Mr. Lemaître on May 2 d.

M. ZeILLER has been elected a member of the botanical section of the Paris Academy of Sciences in the place of the late Adolphe Chatin. M. Zeiller received twenty-five votes, while twenty-two were cast for M. Renault. MM. Bureau Costantin and Mangin were also candidates.

THE following fifteen candidates have been recommended by the Council of the Royal Society for election to membership: Professor Alfred William Alcock, M.B., Mr. Frank Watson Dyson, M.A., Mr. Arthur John Evans, M.A., Professor John Walter Gregory, D.Sc., Captain Henry Bradwardine Jackson, R.N., Mr. Hector Munro Macdonald, M.A., Mr. James Mansergh, M.Inst.C.E., Professor Charles James Martin, M.B., Major Roland Ross, M.R.C.S., Professor William Schlich, Ph.D., C.I.E., Professor Arthur Smithells, B.Sc., Mr. Michael Rodgers Oldfield Thomas, F.Z.S., Mr. William Watson, B.Sc., Mr. William Cecil Dampier Whetham, M.A. and Mr. Arthur Smith Woodward, F.G.S.

AT the annual meeting of the American Academy of Arts and Sciences, held May 8th, the following elections took place: Associate 